\title{
The Nuances of Corporate Social Responsibility (CSR) in India
}

\author{
M. Govindaraj, Aparna Prabhu, N R V Prabhu
}

\begin{abstract}
The fast moving globalization has given room for multiple problems related to the environment we live in. CSR is a tool to sort out the social issues. The ultimate purpose of a corporation is to get profit but at the same time in the process of making money companies should keep in their mind the social responsibility they have towards the society. The procedure of assessing an organization's impact is the look out of CSR and understand the entire environment and all the stakeholders. The activities of CSR need to be sustainable and should in no way affect the goals of the organization. The Indian perspective of CSR initiatives has taken brilliant route where CSR is integrated into the business process. The paper mainly focuses on the various shades of CSR in India presented with statistical date, an extended review on literature, and CSR initiatives by few companies.
\end{abstract}

Key Words: Social responsibility, Organization's impact, employees' attitude and behavior.

\section{INTRODUCTION}

Social duty infers acknowledgment and comprehension of the yearnings of society and guarantee to contribute inside the direction in their accomplishments. Says Steiner. generally, company social duty (CSR) has become a much discussed situation in the scholarly network given the affects that company-condition sporting sports have on representatives, clients, professionals, society, speculators, situation, and nearby communities. Scientists have delivered on to be aware the often growing enthusiasm for CSR and of the business circumstance. partners count on essential process inside the coins related execution of an enterprise organization. The favorable position an enterprise escapes CSR execution may want to beef up clients' unwaveringness, enhance the organisation photograph and notoriety, help for upper hand, pull and hold fine representatives.

to symbolize corporation social responsibility says the world commercial enterprise Council for Sustainable improvement, the moral behavior of an affiliation closer to society - the board appearing capably in its affiliation with special companions who have real enthusiasm for the commercial enterprise. concurrently the CSR trends fluctuates from singular company to enterprise, as there were clashing desires within the concept of businesses' obligation to society.

it is misjudged as a determination of commercial enterprise closer to society but greater than that which inspires the affiliation to be an increasing number of realistic

Revised Manuscript Received on September 14, 2019.

Dr M. Govindaraj, Assistant Professor, College of Management, Jain University, Bangalore, Karnataka, India

Dr. Aparna Prabhu, Architechtural Specifications Manager, Guardian Glass India, Chennai, Tamil Nadu, India.

Dr N R V Prabhu, Principal (Engineering), Gokul Group of Institutions, Piridi. Bobbili, Andhra Pradesh 535 558. India inside the earth. inside the existing scenario the dimensions of sports of corporations are big; they cross their nearby limits and thinking about they get property from society and in no way another time businesses adhere to their antiquated process of advantage making however release their obligation in the direction of its companions via primary course with the aid of way of indicating fear on morals, society and scenario. They guarantee straightforwardness and obligation in its pronouncing that's the precept solution for accomplish practical better hand in CSR. A representative assumes a double assignment of a partner and key device within the execution of company strategies. Such fulfilled companions are submitted in the direction of the exchange and are hopeful, reliable and green in bringing social request.

As indicated by J.R.D Tata, the originator of TATA metallic, CSR is extensively speaking concerned approximately the method of the organization in tending to cultural troubles and of lower in social prices. as a consequence to guide CSR that is a developing improvement, it improves and advances the intrigue and health within the brains of the individuals dwelling in that society.

\section{DEFINITION}

CSR is the gadget with the aid of which an affiliation contemplates and advances its associations with companions for the benefit of anybody, and well-knownshows its determination in such way through reception of appropriate business approaches and methodologies. alongside these strains CSR isn't always philanthropy or simple items. CSR is a way for principal commercial enterprise, via the use of which organisation elements pretty add to the social super. Socially capable groups do not restrain themselves to utilising property to take part in bodily video games that increase truely their blessings. They use CSR to include economic, herbal and social places with the organisation's sports and improvement.

The Act (2013) further expounds the project or tasks figuring out with bodily sports embraced by using the pinnacle managerial team of workers of an enterprise (Board) in compatibility of proposals of the CSR Committee of the Board in step with counseled CSR policy of the company mission to the state of affairs that such strategy will cowl subjects laid out in time table Vll of the Act.

CSR coverage" identifies with the sporting events to be tried in keeping with Section135 of the Act as indicated in schedule VII to the Act and the intake sooner or later, 
barring sports activities embraced in compatibility of usual direction of enterprise of an organisation.

CSR is, along the ones lines, an business enterprise's responsibility to running in a financially, socially and earth possible way whilst adjusting the passion of differing companions.

\section{WHY CSR?}

experts and Scientists are absolutely speakme approximately global warming this is going approximately as a massive danger to the globe. The sports activities taken thru the administration in boost modifications in the general public arrives at sincerely to a restrained degree pursued with the aid of numerous solicitations to corporations to soak up social and herbal issues moreover. The Committee is prescribing sometimes for building up a CSR device that can incorporate each one of the problems concerning the adjustment in most of the people. organisations should be enormous method gamers in wearing CSR via protective fingers with authorities and pass about as a trade professional in wearing alternate to the network and the earth.

\section{CSR AND INDIA}

In India, groups take real endeavors in taking up CSR sports activities and coordinating them into their paintings atmosphere or tradition. The Indian company setting is mounted in order that aside from growing their agencies they moreover contribute for molding affiliation with specific divisions and organizations which might be association thru businesses to create methodologies, strategies and targets for their CSR along spending mission. Such packages are all round planned with treasured dreams and are in affiliation with the agencies' industrial organisation vicinity.

India is the most essential kingdom on this planet to make company social obligation (CSR) obligatory from the 12 months 2014 consistent with the correction of the businesses Act of 2013 ( section one hundred thirty five) in which businesses can likewise positioned their reserve allotment in territories, for example, education, destitution, sexual orientation fairness, and craving as a number one component of any CSR consistence. The change word inside the companies Act 2013, expects corporations to burn via 2 percentage of their ordinary turn-over of 3 years on CSR. but, the prices in the direction of CSR aren't certified in the calculation of assessable salary, the management is rethinking about for this affiliation inside the as of late affords corporations (change) Act 2019. Indian Institute of company Affairs had likewise stated that as a minimum 6,000 Indian organizations can be required to try CSR extends in an effort to follow the preparations of the corporations Act, 2013 with severa groups undertaking those sports clearly because of the truth.

India has crossed a large allotment in 2019 toward CSR after it modified into made required in which a substantial bit is towards steering and aptitudes development ventures, trailed by using medicinal offerings and sanitation activities, the 2 of which can be top desires moreover, at the same time as there has been a selection of 139 percentage in CSR willpower in the route of the most trendy 3 hundred and sixty 5 days thru the high Minister's alleviation Fund. it's far furthermore evaluated that CSR consistence will enhance and make bigger among 90 seven to 98 percent with the aid of FY 2019-2020.

\section{V.STATISTICS ON CSR ( IN INDIA)}

CSR Fund flow in between FY 14-15 to FY 18-19 (INR Cr) is as follows:

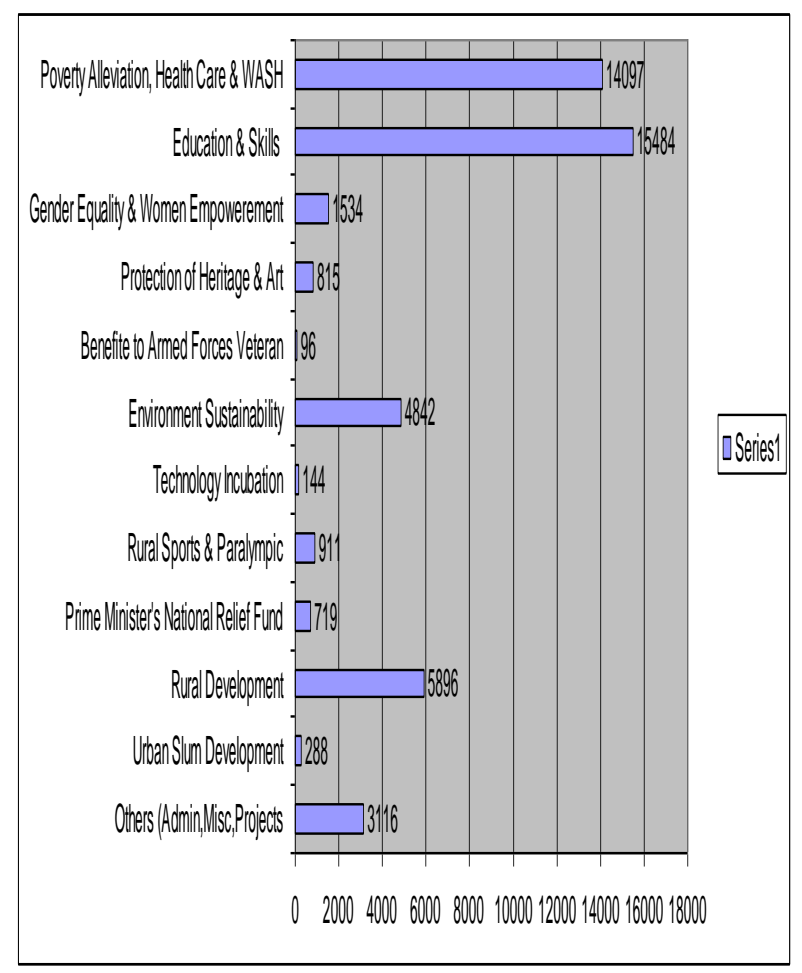

Top 10 states ( in csr funding during fy - $14-15$, fy 18 19) :

\begin{tabular}{|l|l|l|}
\hline State & $\begin{array}{l}\text { CSR } \\
\text { Funding }\end{array}$ & INR Cr. \\
\hline Maharashtra & $15.59 \%$ & 7473 \\
\hline Rajasthan & $6.18 \%$ & 2962 \\
\hline Karnataka & $5.95 \%$ & 2852 \\
\hline Gujarat & $5.28 \%$ & 2531 \\
\hline West Bengal & $4.55 \%$ & 2181 \\
\hline Tamil Nadu & $4.54 \%$ & 2176 \\
\hline Odisha(Orissa) & $4.53 \%$ & 2171 \\
\hline Andhra Pradesh & $4.52 \%$ & 2166 \\
\hline Jharkhand & $3.60 \%$ & 1725 \\
\hline Telengana & $3.23 \%$ & 1548 \\
\hline
\end{tabular}

Published By: 


\section{INDUSTRYWISE CSR CONTRIBUTION}

Top 20 Companies In Csr Funding

\begin{tabular}{|c|c|c|}
\hline S.No. & Company & $\begin{array}{l}\text { Estimated } \\
\text { or } \\
\text { Prescribed } \\
\text { CSR(INR } \\
\text { Cr) }\end{array}$ \\
\hline 1 & Reliance Industries Ltd. & 817 \\
\hline 2 & Tata Consultancy Services Ltd. & 609 \\
\hline 3 & $\begin{array}{l}\text { Oil \& Natural Gas Corporation } \\
\text { Ltd. }\end{array}$ & 518 \\
\hline 4 & Indian Oil Corporation Ltd. & 504 \\
\hline 5 & HDFC Ltd. & 450 \\
\hline 6 & Infosys Ltd. & 376 \\
\hline 7 & ITC Ltd. & 312 \\
\hline 8 & Coal India Ltd. & 271 \\
\hline 9 & $\begin{array}{l}\text { Housing Development Finance } \\
\text { Corporation Ltd. }\end{array}$ & 241 \\
\hline 10 & NTPC Ltd. & 233 \\
\hline 11 & Bharat Petroleum Ltd. & 218 \\
\hline 12 & Hindustan Zinc Ltd. & 209 \\
\hline 13 & Wipro Ltd. & 209 \\
\hline 14 & ICICI Bank Ltd. & 206 \\
\hline 15 & Maruti Suzuki Ltd. & 189 \\
\hline 16 & $\begin{array}{l}\text { Power Grid Corporation of India } \\
\text { Ltd. }\end{array}$ & 183 \\
\hline 17 & HCL Technologies Ltd. & 167 \\
\hline 18 & $\begin{array}{ll}\text { Hindustan } & \text { Petroleum } \\
\text { Corporation Ltd. } & \\
\end{array}$ & 160 \\
\hline 19 & $\begin{array}{ll}\text { Rural } & \text { Electrification } \\
\text { Corporation Ltd. } & \end{array}$ & 158 \\
\hline 20 & Power Finance Corporation Ltd. & 150 \\
\hline
\end{tabular}

Source : https://csrbox.org/CSR-in-India

Above statistics reveal that CSR in India has taken a major step in revolutionizing the environment. The domains of CSR has spread its wings to all areas which shows a drastic transformation of the society as a whole where companies have involved knowing their responsibility.

\section{REVIEW OF RELATED LITERATURE \& RESULTS}

CSR includes of four additives, as indicated by way of Carroll (1991), that's spoken to as a pyramid, whose pinnacle is a humanitarian, trailed with the aid of lawful obligation, financial and social descending.

$\square$ monetary obligation circulate approximately as a key duty of the enterprise as some distance as corporate blessings given the fulfillment of the requirements and dreams for customers.

$\square$ criminal obligation is the way that businesses demonstration as in line with the law. An enterprise that includes on as consistent with the requirements of social duty can be said that he is making an attempt to excessive moral norms.

$\square$ magnanimous obligation receive that the company is "powerful individuals of society" and add to community belongings. The essential angles that contain CSR is responsibility and simplicity in which the enterprise notwithstanding the obligation of a default at the presentation and advantage of money wherein the employer is succesful to partners, for their exhibition in connection to human rights, natural association, moral requirements of corporation, company control, community improvement, and first rate range and employment advent problems.

$\square$ a number of the advantages of CSR in the long run pass about as an answer for accomplish a reasonably-priced top hand in a violent state of affairs is primarily based upon increasing willpower and renovation, solid courting with the network, improve the notoriety and logo photo, pinnacle hand, better budgetary execution.

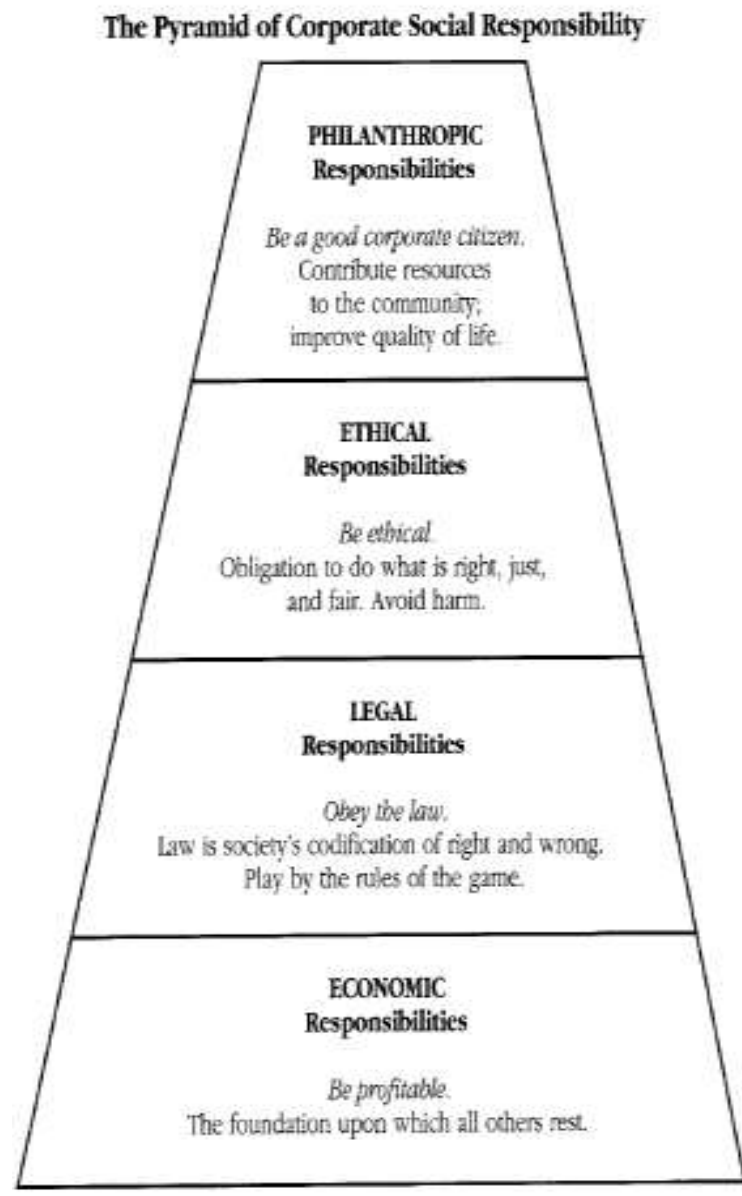

The method for doing CSR by little and medium measured agencies with an organized way to address oversee organisation notoriety and advantage expansion changed into very lots broke down with the aid of Nigel Serbutts (2003). CSR comes as an expectation for little businesses that war for limiting the hazard and obtain more notoriety even though big businesses have this form of significant extensive style of belongings for actualizing CSR bodily activities contrasted with SME's. SME's must have suitable usage of property and execute CSR as a manner to restriction their dangers.

Gond, Crane (2008) et al. examined the assessment of past investigates who determined some rationalization in absence of enthusiasm on company social execution inquire about some of the researchers. Their paper proposed models primarily based at the motives clarified by way of the scientist concerning why the CSP concept has out of place 
its significance and development. The sports of CSP want to be anticipated contrastingly with the goal that analysts can push in advance within the direction of development.

Shah, Bhaskar (2010) for his or her scenario have a look at on Bharat Petroleum corporation Ltd. exposed that a extensive connection exists many of the association and society where the life of the organization definitely is based totally upon the majority. The contributions from the majority like fabric, human and so on were utilized by the employer and consequently gave administrations to the majority. It changed into apparent from the contextual assessment of the BPCL, that the employer has taken a exquisite deal of sports a good way to serve most of the people.

Bansal, Parida, Kumar (2012) recorded in the Bombay stock exchange with the assist of their every year critiques of 30 corporations of eleven elements. shipping device location, Finance and metallic Mining phase, IT and power, Capital products, Telecom, Housing, FMCG, Oil and gas and Cipla have been a part of the additives. the nature and zones of society in which the organisation positioned have been mulled over and presumed that organizations are not running simply you bought benefit however similarly have understood the importance of being social and agreeable. Discoveries of the paper turned into social obligation has commenced to take some other path prompting the fulfillment of CSR.

The economic instances (eleven Jan.2013) featured on Dell's tool of spurring its people in commencement period of CSR. The information opined that agency's worker's is going about as the brilliant power to push the corporation to assist out most people. The movement that the company has related with is essentially in the areas of training, situation and worker welfare. The information likewise investigated on one of a kind agencies like Maruti and Godrej apart from Dell that those agencies in perspective on setting up its humans for network control offers beauty making ready. In particular Maruti runs a software named e-parivartan to prepare the people on community issue and their answer.

Shastri and Singh (2012) in their paper examined the commitments of Indian groups for example HPCL, BPCL, IOCL, energy Grid GAIL, EIL, BHEL and BPC having a place with numerous classifications of PSUs within the route of company social obligation. CSR sporting events of the above groups protected coaching, medicinal offerings, network welfare, girls strengthening, america advancement, situation safety, kids welfare, calamity the executives, philanthropy/presents and supporting not unusual society. The discoveries of the exam exposed the importance of method structure for CSR, utilization, task of spending plan, and a definitive motive for embracing CSR rehearses.

Singh and Sharma (2015) in their paper analyzed the executive machine and CSR procedures and physical video games completed with the useful resource of open phase gadgets for instance Coal India Ltd. furthermore, GAIL. The activities taken incorporate education, information improvement, ladies strengthening wearing sports, improvement of negative and penniless area of society, sustenance, health and sanitation workplaces and provincial improvement. The organizations moreover pursued the required condition of contributing $2 \%$ of the everyday benefit of three short going before budgetary years in the direction of CSR physical sports. The discoveries observed out that these corporations are extremely working for social duty and they're no longer just masking sports beneath section one hundred thirty five of groups Act, 2013 however at the same time are going beyond that.

\section{CONCLUSIONS}

CSR in India has come to beyond limits and isn't virtually philanthropy and objects, and is drawn closer in a often noble and composed way and come to be an indivisible piece of the agency process. CSR organizations are completely delegated who devise specific techniques, procedures and goals for his or her CSR projects and set spending plan to help them. CSR has grow to be an concept wherein companies past their gainfulness and improvement supply an incentive in moderate of a legitimate issue for society and state of affairs, with the useful resource of taking manipulate at the impact of their physical games on partners, condition and all others people from the open place. CSR is not identical as magnanimity and Charity in light of the truth that CSR is a few aspect however a benevolent demonstration of giving and businesses get lengthy haul profits via the CSR activities.

Parcel of facts is offered on CSR spending, techniques and sports activities taken via special corporations in severa zones, but all the data of CSR has been demonstrated subjectively until date. it's far to be located that when the execution of corporations Act of 2013 there no examination directed on CSR which affirms the command of the demonstration at any fee $2 \%$ of ordinary internet advantages of going in advance than three monetary years should be contributed in the path of CSR bodily activities regular with the calendar VII. The paper presumes that there's an extension for destiny research to consider the money related execution pre and submit utilization of required guidelines consistent with the section one hundred thirty five of groups Act, 2013.

\section{REFERENCES}

1. Bansal, Harbajan. Parida, Vinu and Pankaj Kumar (2012). "developing styles of company Social responsibility in India". KAIM magazine of control Vol.four. No. 1-2.

2. Carroll, A. B. (1991). The pyramid of company social obligation: near the ethical control of hierarchical partners. enterprise skylines, 34(four), 39-forty eight.

3. Chaturvedi, Anumeha. (2013). "agencies offer representatives a poke for agency social duty". The economic times (11 Jan.2013).

4. Fiori, G.; di Donato, F.; Federica Izzo, M.F. corporate social duty and corporations execution-An exam on Italian recorded corporations. SSRN Electron. J. 2007, 9, $1-14$.

5. Gond, C. Jean-Pascal and Crane Andrew (2008) "corporate Social duty twisted: Saving the misplaced worldview?" commercial enterprise and Society journal.

6. Kotler, Philip (2000), advertising control, fifth version, 
Prentice corridor, u.s.a..

7. Prabhu, Dr. N.R.V. what is greater, Durga Devi Pradeep, " general quality management: An Organizational Framework on consumer manner and people", UAR Publishing, Chennai, 2012, 12 (2), 366-eighty.

8. Sarbutts, Nigel. (2003). "Can SME"es do CSR? A expert's perspectives at the manner little and medium-sized endeavors can oversee notoriety thru agency social duty." magazine of correspondence the board. Vol.7. No. 4. Pp. 340-347.

9. Saxton, G.D.; Waters, R.D. What do companions like on facebook? looking at open responses to charitable institutions' instructive, limited time, and community constructing messages. J. Open Relat. Res. 2014, 26,280-299.

10. Singh, S. And Sharma, A. (2015). company social duty rehearses in India: analysis of Public businesses, international magazine of commercial enterprise Quantitative Economics and applied control research, ISSN: 2349-5677, 1(11), 33-40 four.

11. Shah, Shashank and Sudhir Bhaskar (2010). "corporate Social responsibility in an Indian Public quarter enterprise: A Case study of Bharat Petroleum enterprise Ltd". Diary of Human Values. Vol. sixteen. No. 2.Pp. 143-156.

12. Shastri, R. And Singh, A. (2012). An Empirical look at on corporate Social duty Practices of Indian Public zone businesses. countrywide conference on emerging challenges for Sustainable business, ISSN: 978-ninety three-81583-46-three.

13. https://www.India-briefing.Com/statistics/companysocial-obligation india-5511.Html/

14. https://csrbox.Org/CSR-in-India 